\title{
The Danube inland waterway transport and its role in Serbia's economic development
}

\author{
Jelena Milanković Jovanov $\bowtie$, Dragoslav Pavić, Jasmina Đorđević, Aleksandra Dragin, \\ Smiljana Đukičin Vučković, Minucsér Mészáros \\ University of Novi Sad; Novi Sad, Serbia; e-mail: milankovicjovanov@gmail.com
}

\begin{abstract}
The Danube river waterway, i.e. the Pan-European Corridor VII, is considered as one of the most significant transport corridors in Europe. It runs through ten countries, including Serbia (the Serbian part of the river is $588 \mathrm{~km}$ long), which is why it is one of Serbia's priorities to develop inland water transport. The system of waterways provides a viable alternative to roads and rail systems. Moreover, it is crucial for regional development. The Danube River offers excellent opportunities for freight, passenger and tourist inland water transportation. However, the navigability potential of the Danube River still remains largely underrealized in Serbia: despite the high quality of waterways, inland water transport accounts for only $4.7 \%$ of the total transport. This paper deals with the advantages of inland navigation and the major characteristics of the Danube waterway in Serbia. In Serbia, the Danube is mainly used for freight and passenger transportation and for the development of nautical tourism. There are a number of important projects that are currently being implemented in Serbia, such as the construction of new port facilities and marinas. The paper also discusses the negative factors impeding regional development in the sphere of waterways and water transport in Serbia, primarily the lack of funding for maintenance and improvement of the river's navigability.
\end{abstract}

\section{KEYWORDS}

Danube, inland waterway, Serbia, transport, sustainable regional development, tourism

\section{ACKNOWLEDGMENTS}

This research was supported by the Provincial Secretariat for Science and Technological Development, ECAP Vojvodina (Project 114-451-2465/2018-02). This paper is based on $\mathrm{PhD}$ thesis Danube as a Transport Artery and Axis of Development in the Republic of Serbia defended by Jelena Milanković Jovanov at the Department of Geography, Tourism and Hotel Management in 2015 and $\mathrm{PhD}$ thesis Cruising Along the Corridor VII and Nautical Tourism in Serbia defended by Aleksandra Dragin at the Department of Geography, Tourism and Hotel Management in 2008.

\section{FOR CITATION}

Milanković Jovanov J., Pavić D., Đorđević J., Dragin A., Đukičin Vučković S., \& Mészáros, M. (2018) The Danube inland waterway transport and its role in Serbia's economic development. R-economy, 4(3), 105-114. doi: 10.15826/recon.2018.4.3.015

\section{Дунайский национальный водный транспорт и его роль в экономическом развитии Сербии}

\author{
Е. Миланкович $\bowtie$, Д. Павич, Ж. Джордевич, А. Драгин, С. Джукичин Вучкович, М. Месарош \\ Нови-Садский университет, Нови-Сад, Сербия; e-mail: milankovicjovanov@gmail.com
}

\section{PEЗЮME}

Дунайский водный путь, т. е. Паневропейский коридор VII, считается одним из самых значительных транспортных коридоров в Европе. Он проходит через десять стран, включая Сербию (сербская часть реки составляет 588 км), и поэтому является одним из приоритетов Сербии по развитию внутреннего водного транспорта. Система водных путей является жизнеспособной альтернативой дорожным и железнодорожным системам. Более того, это важно для регионального развития. Река Дунай предлагает прекрасные возможности для грузовых, пассажирских и туристических внутренних водных перевозок. Однако потенциал судоходства в реке Дунай по-прежнему реализован в Сербии не полностью: несмотря на высокое качество водных путей, внутренний водный транспорт составляет лишь 4,7\% от общего объема перевозок. В этом документе рассматриваются преимущества внутреннего судоходства и основные характеристики водного пути Дуная в Сербии. В Сербии Дунай в основном используется для грузовых и пассажирских перевозок и для развития водного туризма. В настоящее время в Сербии реализуется ряд важных проектов, таких как строительство новых портовых сооружений и пристаней для яхт. В статье также обсуждаются негативные факторы, препятствующие региональному развитию в сфере водных путей и водного транспорта в Сербии, в первую очередь отсутствие финансирования для поддержания и улучшения судоходства реки.

\section{КЛЮЧЕВЫЕ СЛОВА}

Дунай, внутренний водный путь, Сербия, транспорт, устойчивое региональное развитие, туризм

\section{БЛАГОДАРНОСТИ}

Исследование поддержано провинциальным секретариатом по науке и технологическому развитию, ECAP Vojvodina (проект 114-451-2465 / 2018-02). Статья основана на кандидатских диссертациях, защищенных на кафедре географии, туризма и гостиничного менеджмента Е. Миланкович Йованов «Дунай как транспортная артерия и ось развития в Республике Сербия» в 2015 г. и А. Драгиной «Крейсерская по коридору VII и Морской туризм в Сербии» в 2008 г.

\section{ДЛЯ ЦИТИРОВАНИЯ}

Milanković Jovanov J., Pavić D., Đorđević J. Dragin A., Đukičin Vučković S., \& Mészáros, M. (2018) The Danube inland waterway transport and its role in Serbia's economic development. R-economy, 4(3), 105-114. doi: 10.15826/recon.2018.4.3.015 


\section{Introduction}

The Danube River has always played a significant role in human geography, serving men as a pathway in migration, trade, and war. Nowadays the Danube is a popular transport route connecting Central and Eastern Europe. The river flows through the regions of intensive industrial and agricultural production, densely populated areas with substantial development potential. Prior to the construction of the Suez Canal, the role of the Danube had been extremely important due to the fact that the shortest route connecting Europe and Asia went through the Black Sea. Over sixty of the Danube's tributaries are navigable, which contributes to the transportation importance of the river. The role of the Danube was enhanced by the construction of the Main-Danube canal, which connects the Northern Sea and the Black Sea and creates a $3,500 \mathrm{~km}$ waterway [1].

The Republic of Serbia lies at the crossroads of the most important Pan-European traffic routes, such as the road and railway Corridor X and waterway Corridor VII (the Danube navigable corridor), which has a great significance for the country as it links north and south, east and west. The Danube with the total length of $1,600 \mathrm{~km}$ is the backbone of inland waterways in Serbia [2]. In addition, there are the Danube's large tributaries, the Tisza and the Sava Rivers, and the navigable canals within the hydrosystem Danube-Tisza-Danube. All these navigable routes are connected to the Danube River and are a part of the Trans-European Corridor VII waterway from Rotterdam to Sulina.

High population density also reflects the importance of the Upper Danube Basin in Serbia. The total population in municipalities located near the Danube River is $2,013,646$ people or $28.8 \%$ of the total population of Serbia. Population density in this area is 150 inhabitants per $\mathrm{km}^{2}$, which is twice as many as the country's average $\left(80.5 \text { inhabitants per } \mathrm{km}^{2}\right)^{1}$.

The Danube River is crucial for the development of trade, services and tourism in Serbia [2;3]. The Serbian part of the Danube is navigable and is actively used for freight transportation. The level of the river traffic varies from country to country and depends on the political and economic situation. Political stability and closer economic ties have had a positive impact on the development of the transport system in former Yugoslav republics such as Serbia and Croatia. For instance, there has been a tenfold

${ }^{1}$ Republic Statistical Office. 2012. Census of Population, Households and Dwellings in the Republic of Serbia, 2011, Vol. 2, Age and Gender, data by settlements, Belgrade. increase in freight traffic on the Danube as compared to twenty years ago. Yet, the transport capacity of the river is still underused, especially we if compare it to that of the Rhine, which is ten times higher ${ }^{2}$ [4]. In the Serbian part of the Danube, the lack of investment into the maintenance of waterways and the lack of careful planning has led to deterioration of river and canal navigation in such spheres as freight and passenger transportation and nautical tourism.

\section{Inland Navigation through the Danube Waterway in Europe and Serbia}

The Danube has a great significance for all the countries which it flows through: Germany (14.54\%), Austria (8.82\%), Slovakia (4.34\%), Hungary $(10.49 \%)$, Croatia (3.47\%), Serbia (14.82\%), Romania (27.1\%), Bulgaria (11.87\%), Moldova (0.01\%) and Ukraine (4.54\%). 1,070.9 km of the river (or 37\% of its total length) are state borders. Four countries: Croatia, Bulgaria, Moldova and Ukraine are positioned on only one riverbank ${ }^{3}$.

There are numerous ways to use the Danube River for freight transport, hydropower generation, industrial and residential water supplies, irrigation, and fishing. Navigation and freight transport play the greatest role in economic development, especially after the construction of the canals such as the Danube-Black Sea Canal and the Main-Danube Canal. The water of the Danube is used in industry, but also in agriculture, especially for irrigation ${ }^{4}$. River transport has a number of advantages such as cost effectiveness and profitability: as Jean Pierre Rissoan (1994) said, "river-sea transport pollutes less and can also provide an alternative to congested roads and railways. Door-to-door journeys by river-sea transport seem destined for future growth" [5]. According to the Economic Commission for Europe (1996; 2011), some of the advantages of inland waterway transportation include cost effectiveness; the lowest propulsion energy consumption; navigation safety; reduced pollution, and so on ${ }^{5}$.

\footnotetext{
${ }^{2}$ Danube Navigation Statistic for 2009-2010; Encyclopedia Britannica. Retrieved from http://www.britannica.com/

${ }^{3}$ Danube Commission. Retrieved from http://www.danubecommission.org/

${ }^{4}$ Encyclopedia Britannica. Retrieved from http://www. britannica.com/

5 The White Paper on Trends in and Development of Inland Navigation and its Infrastructure. Retrieved from www. unece.org/trans/doc/finaldocs/sc3/TRANS-SC3-138e.pdf; The White Paper on Efficient and Sustainable Inland Water Transport in Europe. Retrieved from http://www.unece.org/fileadmin/DAM/trans/main/sc3/publications/WhitePaper Inland Water Transport 2011e.pdf
} 


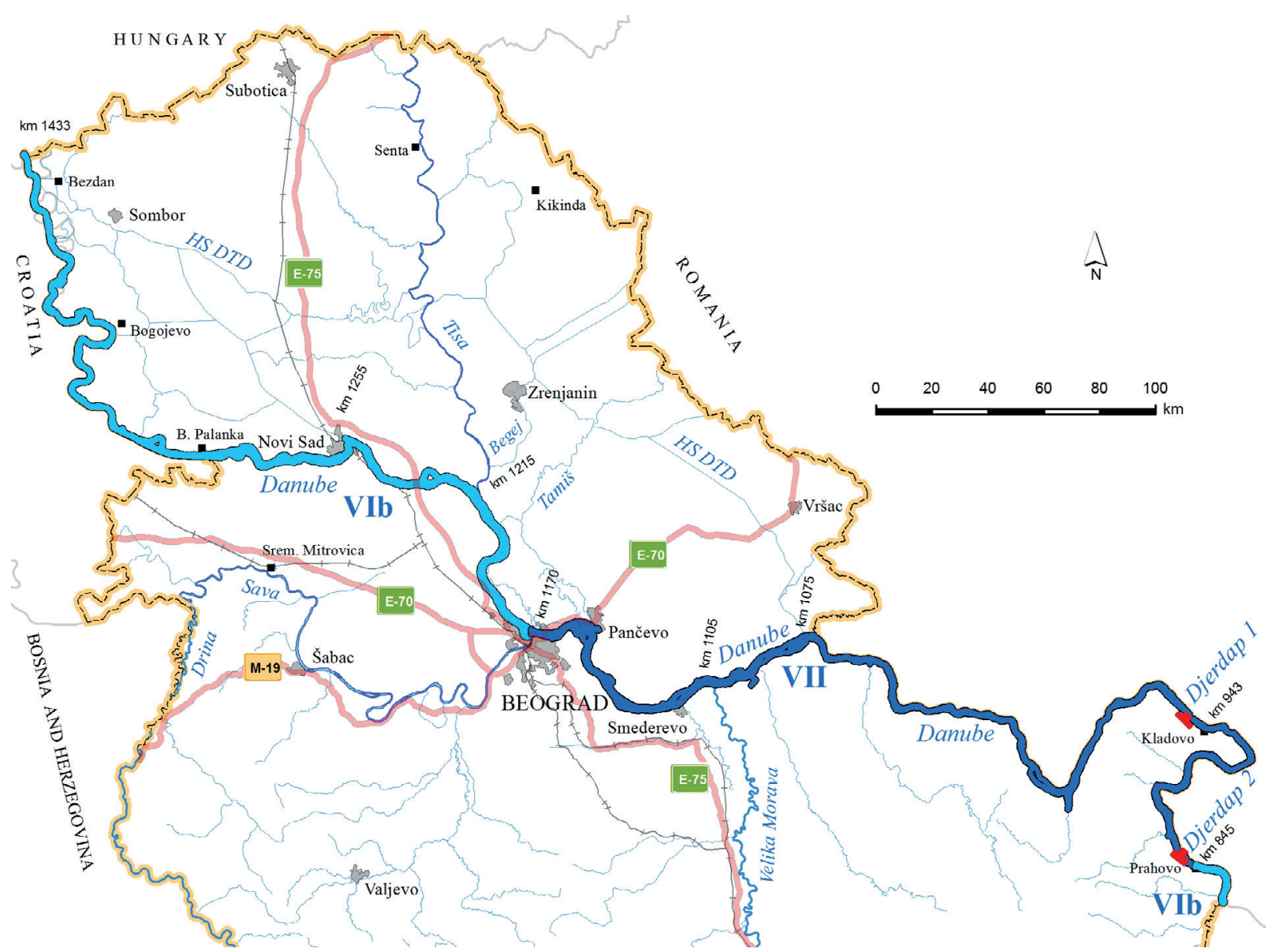

Figure 1. The Danube River in Serbia (Corridor VII)

Source: Base map source (Global map V2). Retrieved from http://www.iscgm.org/gmd/

The Serbian part of the Danube is a typical lowland river 400-1,200 m wide, approximately $19 \mathrm{~m}$ deep with the water speed of $3.5-4.0 \mathrm{~km} / \mathrm{h}$. Prior to the building of the hydroelectric power plant and navigation system Djerdap, the Danube had had the characteristics of a mountain river (approximate speed of $18 \mathrm{~km} / \mathrm{h}$ ) in Djerdap sector. The construction of the above-mentioned system significantly reduced the river's speed to only $0.3 \mathrm{~m} / \mathrm{s}$ or $1.1 \mathrm{~km} / \mathrm{h}$.

The Danube is the most important element of the inland waterway system in Serbia. With the Sava and the Tisa rivers, it creates a network of waterways $1,680 \mathrm{~km}$ long [2].

Serbia was one of the seven countries that established the Danube Commission in 1948, thus accepting the obligation to maintain and improve navigation conditions of the river. One of the most significant recommendations of the Danube Commission is to assure the minimum depths of $2.5 \mathrm{~m}$ and fairway widths of $180 \mathrm{~m}$ at low water levels.

The Danube's section in Serbia $(588 \mathrm{~km})$ is navigable for all types of river ships; it may be di- vided into four sectors, corresponding to two waterway classes (European Conference of Ministers of Transport, 1992) $)^{6}$ :

- the sector between the Hungarian border $(\mathrm{km} 1433+000)$ and Belgrade $(\mathrm{km} 1166+000)$ has hydrologic and hydraulic regime characteristics;

- the sector between Belgrade $(\mathrm{km} 1166+$ $000)$ and the dam Djerdap I $(\mathrm{km} 942+000)$ is slowly moving canalled water and corresponds to the waterway class VII;

- the sector between the dam Djerdap I (km $942+000)$ and Djerdap II $(\mathrm{km} 863+550)$ was also canalled corresponding to the highest waterway class VII;

- downstream the dam Djerdap II $(\mathrm{km} 863+$ $550)$ up to the Bulgarian border $(\mathrm{km} 845+000)$, the Danube's course is regulated by various constructions. The maximum vessel dimensions are similar to those in the upstream sectors. However,

${ }^{6}$ European Conference of Ministers of Transport (1992). Resolution No. 92/2 on New Classification of Inland Waterways (report). Retrieved from http://www.internationaltransportforum.org/IntOrg/acquis/wat19922e.pdf 
there is a serious threat for the navigation as there are about 200 sunken WWII ships, some of them still loaded with explosive substances, which also endangers VIb waterway class in this sector.

\section{Fleet}

According to the Danube Navigation Statistics, from 1962 (3,142 vessels) to 1990 (5,754 vessels), the fleet size grew steadily. In 2000, there was a considerable decrease in the number of vessels. Afterwards, the number of vessels fluctuated insignificantly (Figure 2). However, despite the fluctuations, there was a general upward trend in the number of vessels from 1962 to 2013; the ships' loading capacity increased as well.

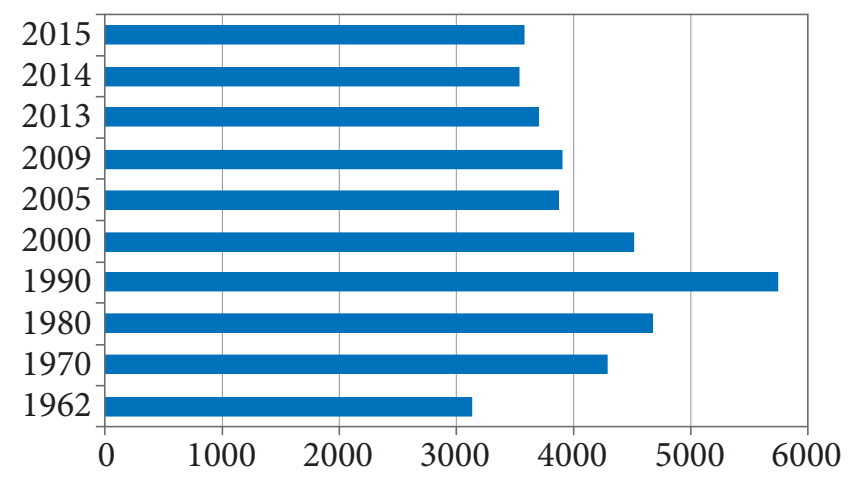

Figure 2. The total number of vessels of the Danube countries (1962-2015)

Source: Danube Navigation Statistics for 2009-2010, 2012-2013, 2014-2015

Most vessels in the Danube fleet are used in Germany, Austria, Romania and Ukraine. The number of vessels in Serbia, Croatia and Moldavia is $5 \%$ lower than the total number of vessels on the Danube.

Regarding the tonnage of ships on the Danube, Romania ranks first with its share of $40 \%$, then follows Ukraine with 21\%, Serbia with 13\%, whereas Croatia and Moldova have the smallest shares, $2.5 \%$ and $1 \%$ respectively ${ }^{7}$.

The priority areas for the development of the Danube fleet are as follows ${ }^{8}$ : modernisa-

${ }^{7}$ European Conference of Ministers of Transport (1992) Resolution No. 92/2 on New Classification of Inland Waterways (report). Retrieved from http://www.internationaltransportforum.org/IntOrg/acquis/wat19922e.pdf; Inventory of Data on the Strategic Inland Waterway Projects. 2011. PLATINA. Retrieved from http://www.naiades.info/repository/public/ article downloads/file/422 d5-5 24-03-2011 (final web version).pdf

${ }^{8}$ The White Paper on Efficient and Sustainable Inland Water Transport in Europe. Retrieved from http://www.unece.org/ fileadmin/DAM/trans/main/sc3/publications/WhitePaper Inland Water Transport 2011e.pdf tion of the fleet; introduction of new logistics systems; implementation of the River Information Services and introduction of new transport technologies.

Table 1

Fleet, its structure and main types of vessels in Serbia in 2015

\begin{tabular}{|l|r|r|r|r|r|r|}
\hline Indicator & $\begin{array}{c}\text { Mo- } \\
\text { tori- } \\
\text { zed } \\
\text { vessels }\end{array}$ & Tugs & $\begin{array}{c}\text { Pu- } \\
\text { sher } \\
\text { ves- } \\
\text { sels }\end{array}$ & $\begin{array}{r}\text { Towed } \\
\text { barges }\end{array}$ & Pushed \\
barges & Total \\
\hline $\begin{array}{l}\text { Number } \\
\text { of units }\end{array}$ & 97 & 94 & 65 & 228 & 180 & 664 \\
\hline $\begin{array}{l}\text { Total po- } \\
\text { wer (kW) }\end{array}$ & 37,929 & 24,768 & 55,388 & - & $-118,085$ \\
\hline $\begin{array}{l}\text { Total } \\
\text { carrying } \\
\text { capacity (t) }\end{array}$ & 88,066 & - & $-294,001$ & 169,101 & 551,168 \\
\hline \multicolumn{7}{|c|}{ Source: Danube Navigation Statistics for 2014-2015. } \\
\hline
\end{tabular}

According to the Danube Navigation Statistics for 2014 and 2015, the total carrying capacity of vessels in Serbia is 551,168 tonnes, whereas the total power is $118,085 \mathrm{~kW}$.

\section{Port infrastructure}

According to the Danube Commission data, there are 91 commercial ports on the Danube River and its tributaries, out of which 11 ports are situated in Serbia. There are 8 international ports in the Serbian sector of the Danube: Apatin, Bezdan, Bačka Palanka, Novi Sad, Beograd, Pančevo, Smederevo and Prahovo, the remaining three national ports are Titel, Veliko Gradište and Kladovo. According to the Danube Navigation Statistics for 2014-2015, the port Pančevo is one of the largest ports on the Danube, belonging to the group of ports with the annual cargo turnover of more than 1 million tonnes (Figure 3).

Ports in Serbia have significant capacity but they are also technologically outdated, due to the lack of financial support for their maintenance and development. The usage of port capacities reaches only $30 \%$ on average due to the lack of transhipment goods. Low capacity utilisation occurs for several reasons, such as the outdated technical equipment in ports; flawed systems for combined and intermodal transport; and declining industrial production in Serbia. The development of intermodal transport and the promotion of combined transport are crucial for future development of transport in Europe [6]. Most ports in Serbia are connected to the main rail and road traffic routes in the country. Only the ports in Pančevo and 


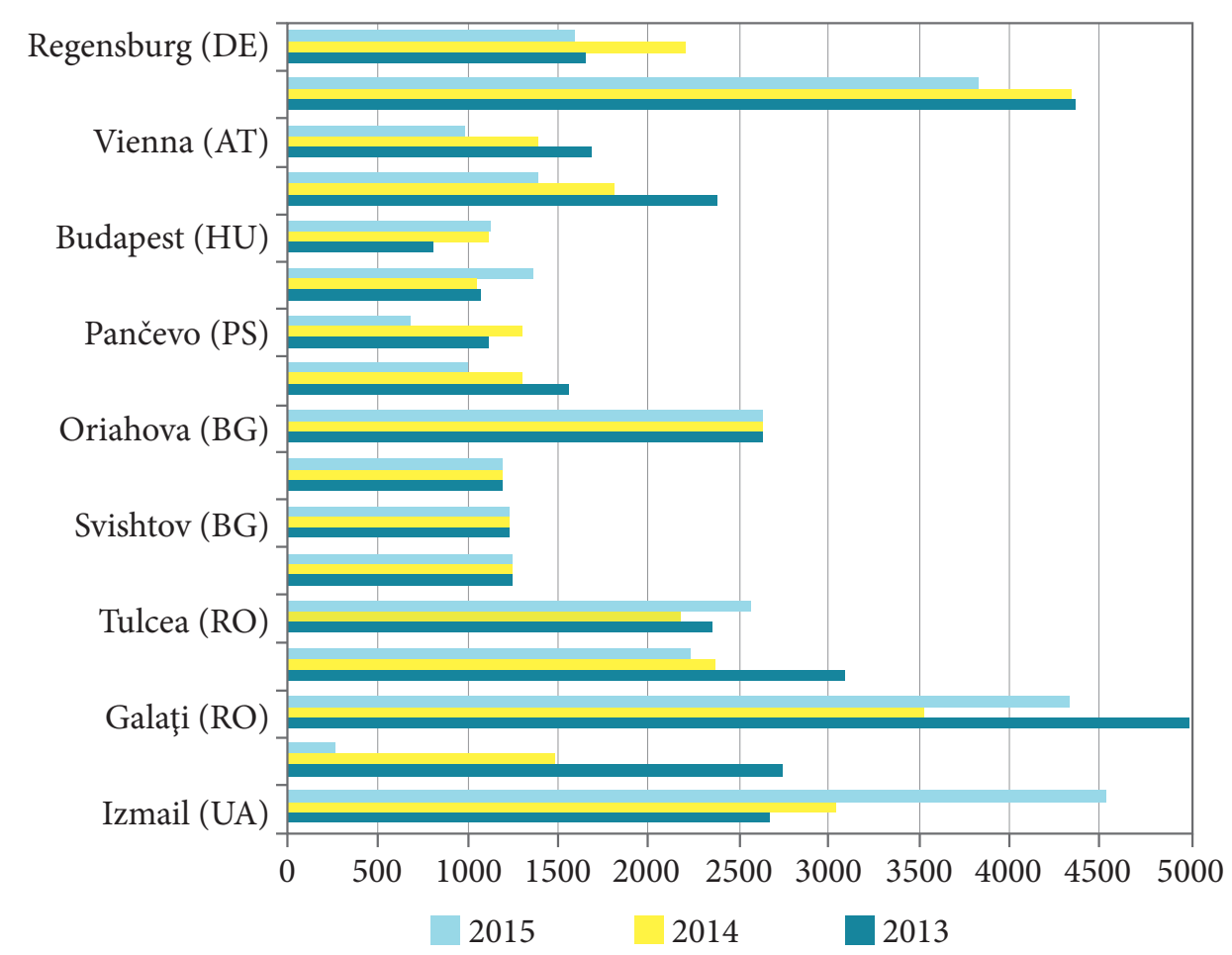

Figure 3. Major ports on the Danube with cargo turnover of more than $1 \mathrm{mln} . t(2013 ; 2014 ; 2015)$

Source: Danube Navigation Statistics for 2012-2013 and 2014-2015

Belgrade have container terminals and none of the ports have Ro-Ro terminals, which is a serious drawback. Ro-Ro transport and Ro-Ro terminals could be used not only for domestic lorry carriers, but also for foreign ones (from Turkey, Bulgaria, and Macedonia), which would make it possible to transport lorries by ship and thus cut transportation costs. The project for constructing multimodal facilities in port Dunav in Pančevo is already well under way. This project has turned out to be successful as it requires minimum investment (primary infrastructure, ground preparation $)^{9}$. In addition to commercial ports, in line with the latest trends in nautical tourism, a new marina has recently been built in Apatin, which is the first international marina on the Danube in Serbia, out of the seventeen planned, and it offers berths for 400 (120 for large yachts) vessels and dry-docking covering the area of $2,500 \mathrm{~m}^{2}$.

\section{The Development of Freight and Passenger Transportation and Nautical Tourism in Serbia}

Until the mid-twentieth century, the Danube waterway in Serbia was primarily used for trans-

\footnotetext{
${ }^{9}$ Regional Development Strategy of the Republic of Serbia for the period 2007-2012 (2005). Government of Republic of Serbia, Belgrade.
}

portation of passengers and goods. The development of road and railway transport somewhat reduced the passenger traffic on the Danube, although this trend was partially compensated for by different forms of nautical tourism. Nowadays, this waterway is mostly used for transportation of goods and tourism.

\section{Heavy load transport}

Despite the favourable conditions for the operation of inland waterway transport in Serbia, there are a number of impediments to its development such as the bad infrastructure. The most important ports are Belgrade, Pančevo, Smedervo and Prahovo and they enjoy a very good connection with surface roads. Ports Belgrade and Pančevo have container terminals.

According to the Statistical Office of the Republic of Serbia, the tonnage carried via the Serbian part of the Danube abruptly decreased after 1990. The period of decline coincided with the period of political instability and economic recession in the country. Afterwards, there was a period of growth, which reached its peak in 2005. Since then, there has been a decline and this indicator's values have never got back to the 2005 level (Figure 4). 


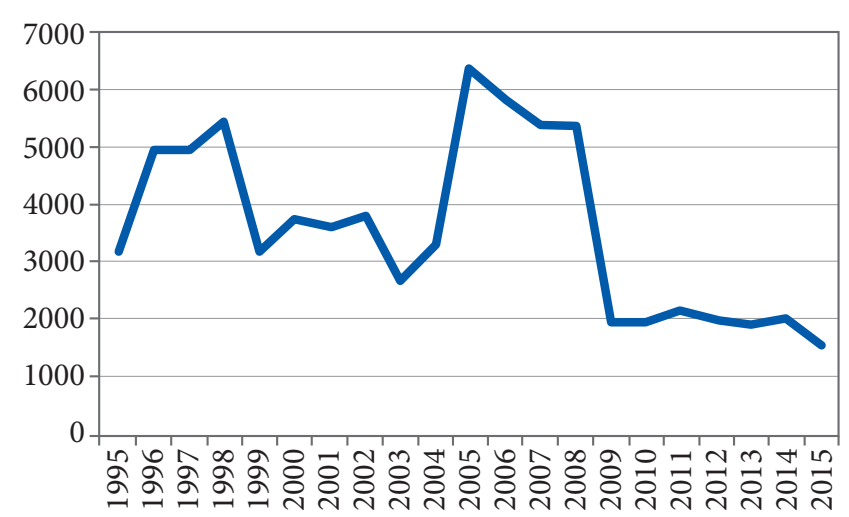

Figure 4. The total tonnage carried on the Danube in Serbia in 1995-2015 (thousands of tons)

Source: Statistical Office of the Republic of Serbia.

Transport, Storage and Connections Bulletin 2004, 2010 and 2016

Out of the total tonne-kilometres handled in inland waterways in Serbia, the Danube accounts for $97 \%$. Inland traffic makes up over $50 \%$ of goods turnover; transit only has a small share, while the transport of goods between foreign ports is almost negligent (see Figure 5).

The goods transported via the Danube are very diverse: iron ore $(25.6 \%)$; processed and unprocessed metals $(22.7 \%)$; coal (9.1\%); oil and oil derivatives (8.5\%); cement (7.5\%); grain goods (6\%); processed metals of metal industry (5.4\%); wood (4.3\%); coloured metals ores (3\%); finished metal products $(2.7 \%)$; and agricultural goods such as fodder (1.6\%) [7]. The Inventory of Data on the Strategic Inland Waterway Projects $(2011)^{10}$

${ }^{10}$ Inventory of Data on the Strategic Inland Waterway Projects. 2011. PLATINA. Retrieved from http://www.naiades. info/repository/public/article downloads/file/422 d5-5 2403-2011 (final web version).pdf demonstrates that the transportation of agricultural, industrial, chemical and metal products will continue to grow due to the improvement in the infrastructure between Budapest and Belgrade, between Romania and Bulgaria and in the area of Vienna. The increase is to be expected in East Europe, including Serbia.

\section{Passenger transport}

The Danube holds a lot of potential as a waterway for passenger transport. This potential, however, is largely underused, as only a few countries in the Danube region have strategies for water transport development. According to the data of the Danube Commission, the highest number of registered passenger ships was recorded in Hungary, Germany, Ukraine and Romania in 2010. These are also the leading countries in terms of domestic passenger-kilometres, whereas the largest number of international passengers is recorded in Ukraine and Germany. Furthermore, according to the Danube Commission, the total passenger kilometres on the Danube in all countries is $21,047 \mathrm{~km}$ in national transport and $22,404 \mathrm{~km}$ in international transport ${ }^{11}$.

Domestic passenger transport virtually does not exist in Serbia and is mostly tourism-oriented. About seventy years ago, passenger ships were travelling along the Danube not only from Novi Sad to Sremska Kamenica, but also to Vienna, Regensburg and Constanca. Hydrowing ships were running regularly between Belgrade and Novi Sad thirty years ago. At that time, passenger ships

${ }^{11}$ Danube Commission. Retrieved from http://www.danubecommission.org/

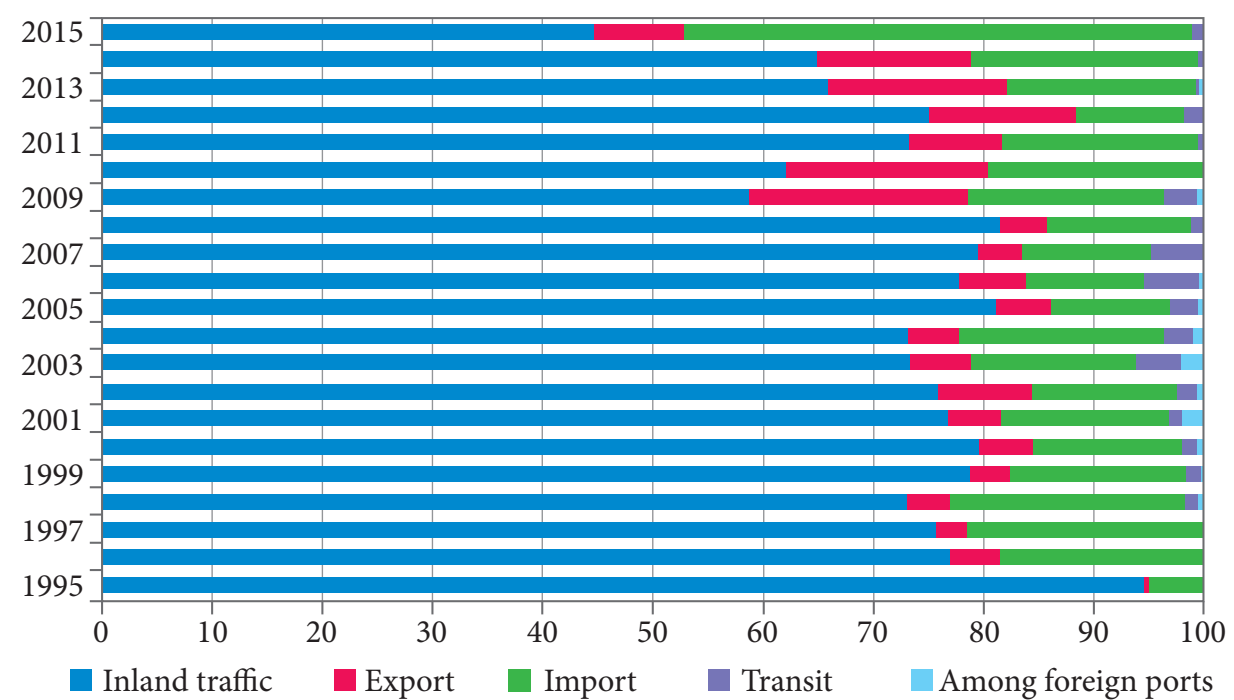

Figure 5. Share of goods transported through the Danube waterway in Serbia between 1995 and 2015, \% 
were operating on the Tisza River, too. Small ships ran from Novi Sad to Bečej several times a day (on the Danube from Novi Sad to the mouth of the Tisa, then on the Tisa to Bečej), and three times per week from Belgrade to Senta (on the Danube from Belgrade to the mouth of the Tisa, then on the Tisa to Senta).

There have been attempts to revive this form of transport lately. For instance, the water taxi is very popular in Budapest (Hungary): it runs at the speed of $50 \mathrm{~km} / \mathrm{h}$ and transports passengers from southern districts to the centre and to the north of the city. Similarly, there is daily transport service between Regensburg, Deggendorf, Passau, Linz and Vienna ${ }^{12}$.

\section{Nautical tourism}

Nautical tourism has been developing worldwide due to the boom of cruise industry in the last four decades. The main forms of nautical tourism include individual navigation of vessel owners, boat charter (renting of ships and sailboats) and river cruises (international tourist cruises). According to the Strategy of Tourism Development in the Republic of Serbia ${ }^{13}$, nautical tourism in Serbia uses the strategic potential of the Danube, the leading river cruising destination in Europe. Furthermore, according to the same source, the main spheres for the development of nautical tourism in the country are individual navigation (this segment is mostly based on local demand); charter (this segment requires the appropriate infrastructure and is underdeveloped at the moment); and river cruising (this segment is very popular and is enjoying explosive growth).

As for individual cruises on the Danube, most of the vessels currently in use are old and the equipment is outdated, which explains the low demand for ship berths in marinas. The current number of vessels used for recreational purposes on the Danube in Serbia is negligible (for example, in Apatin it is less than ten vessels a year). It is expected that old vessels will soon be replaced by new ones and that the number of vessels will be increasing together with the development of nautical tourism in Serbia. It has been estimated that the demand for ship berths in marinas on the Danube (domestic vessels) is unlikely to increase by more than $20 \%$ in the following years.

\footnotetext{
12 Donauschiffahrt WURM+KOECK. Retrieved from http://www.donauschiffahrt.de/en/

13 Strategy of Tourism Development of the Republic of Serbia for the Period 2015-2025 (2015). Ministry of Traffic, Tourism and Telecommunications, Belgrade.
}

The well-equipped nautical route on the Danube and the excellent offer of marinas and other tourist products in Serbia are expected to attract approximately $30 \%$ of the estimated number of vessels to marinas annually. According to the study of marina network in Vojvodina Region, the total number of vessels using marinas is likely to reach 4,100. Moreover, it is expected that Vojvodina (16 of 28 municipalities on the Danube in Serbia) would need about 500 berths for foreign vessels in marinas on the Danube by 2025.

The Serbian sector of the Danube has been suffering from the lack of investment. Until recently, there have not been any marinas, i.e. the nautical tourism infrastructure still leaves much to be desired. This problem could be addressed through the reconstruction of the existing piers and ship berths, which could be converted into marinas. A case to illustrate this solution is the marina in Apatin opened in 2009, which is the only Serbian marina on the Danube. Lately, more investment has been made in pier reconstruction in Belgrade and Novi Sad ${ }^{14}$ [8].

Cruise industry, which has been growing dynamically, has a powerful impact on the world economy. Cruises generate over 450,000 jobs with total salaries of about 15 billion US dollars. In 1998, the World Tourist Organisation described five types of tourism types that would be in most demand in the next two decades: tourist cruises, cultural tourism, event-based tourism, eco-tourism and thematic tourism. The highest increase in tourism cruises demand is expected in the Danube region countries: Hungary, Romania, Slovakia, Croatia, and Serbia. The target markets are the USA, Germany, France, Great Britain, and Austria.

Serbia holds considerable potential for the development of nautical tourism that needs to be realized [3]. This fact has been confirmed by the constant increase in the number of cruise ships arriving in Belgrade and other ports in Serbia (Figure 6). According to the data of the Danube Tourist Commission, over 10,000 tourists cruised along the lower Danube ${ }^{15}$ and about 119,000, along the middle and upper Danube in 2002. By October 2004, over 22,000 tourists from cruise ships visited Novi Sad, over 43,000 Belgrade, and

${ }^{14}$ Hadžić, O. (2005). The Growth of the Cruise Tourism as a Chance for Repositioning Serbia on Tourism Market. (Paper presented at the meeting of University of Novi Sad, Faculty of Natural Science and Mathematics, Novi Sad).

${ }^{15}$ Danube Tourist Commission. Retrieved from http:// www.danube-river.org 
over 60,000, the Danube Delta. In 2004, the turnover on the Danube was 150,000 tourists. The data indicate significant increase in the demand for cruises in the lower Danube. The number of tourists buying river cruises increased by $26.1 \%$ in 2004 (compared to 2002) (Figure 6).

Therefore, we can conclude that there was a dramatic increase in the demand for cruises in the lower sector of the Danube [9-11]. Moreover, there are two national parks located on the right bank of the Danube - Fruška Gora and Djerdap, which could potentially attract large number of visitors in the future $[12 ; 13]$.

\section{Priority projects for the improvement of the Danube waterway in Serbia}

The Republic of Serbia aims to improve its system of inland waterways, provide their maintenance and ensure safe navigation. The pending Law on Navigation Safety and Ports would regulate navigation on the rivers; modernisation of ports and piers, application of River Information Services, and so on.

The European Strategy for the Danube encompasses a number of projects for the development of infrastructure, transport, logistics and tourism on the Corridor VII. The focus is on three priority areas: mobility and multimodality (road, rail, and air routes, inland waterways); promotion of sustainable energy; and promotion of culture and tourism. In line with the Strategy, Serbia's is now implementing the following priority projects on the Danube River ${ }^{16}$ :

${ }^{16}$ General Master Plan for Transport in Serbia. Annex III (2009). Transport on Inland Waterways, Belgrade.
- major overhaul of the navigation lock at Djerdap I and Djerdap II (the works on Djerdap I are already in progress);

- removal of World War II sunken vessels near Prahovo;

- removal of the old bridge and construction of the new railway bridge in Novi Sad (in progress);

- hydro-technical works;

- implementation of the River Information Services (RIS implementation project on the Danube river in Serbia, started in 2009, reached its final phase).

The key projects for improvement of tourism infrastructure on the Serbian part of the Danube are as follows:

- marina on the Danube River near Novi Sad;

- establishment of the Information Centre for Nautical Tourism and smaller information points on the Danube;

- pier in Zemun;

- Marina OASA (Belgrade).

Their realization would contribute to safe and efficient navigation on the Danube and would set higher ecological standards on the Serbian section of the Corridor VII. Most of the above-mentioned projects have already been launched, except for the project for removal of sunken vessels and unexploded bombs near Prahovo, which is being delayed due to the lack of funds.

\section{Conclusion}

Serbia's location at the crossroads of the major European transport corridors (water, road, rail, and air) provides it with opportunities

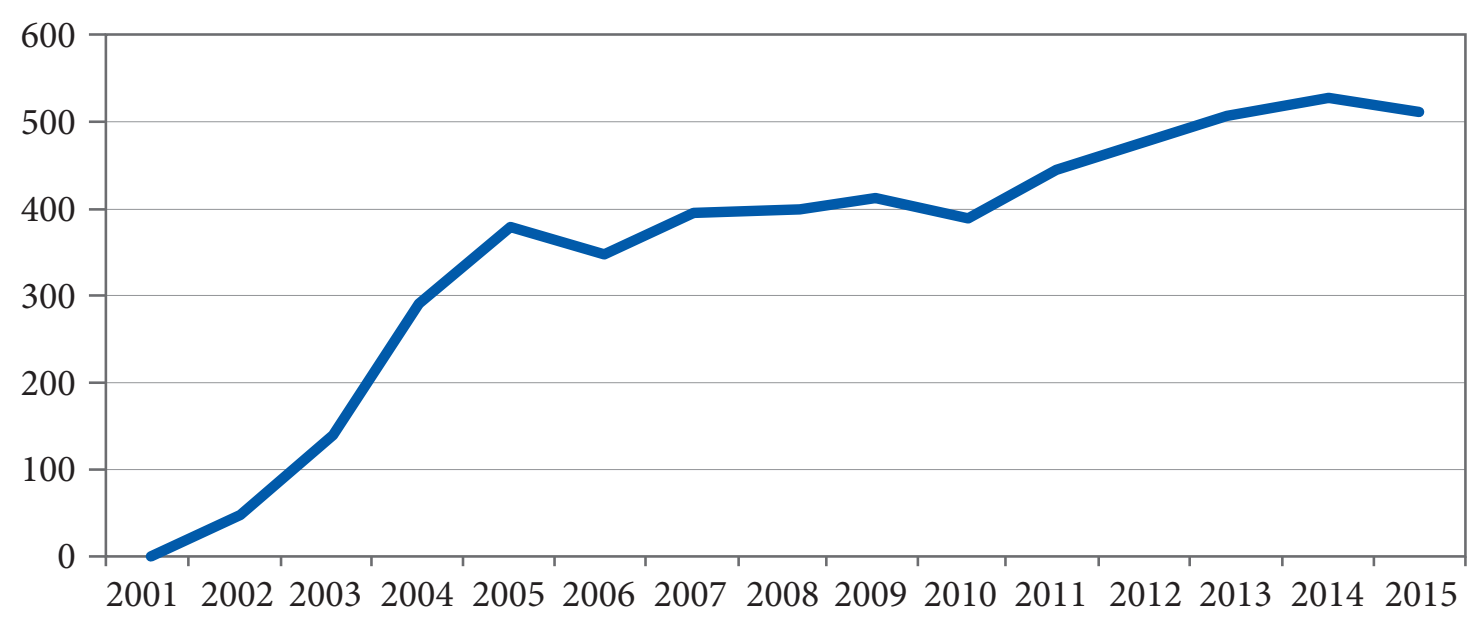

Figure 6. The total annual number of river cruisers in Belgrade in 2002-2015

Source: Official data of the port of Belgrade 
for sustainable economic development, which makes the Danube or the Corridor VII crucial for the country's prosperity. However, despite the advantages the Danube offers, its navigation potential remains underrealized for a number of reasons, primarily economic ones. Although Serbia accounts for $13 \%$ of the ship tonnage in the Danube region, it's fleet is old and outdated and on average only $30 \%$ of the port capacities due to the lack of goods for transhipment. As Serbia is currently in the process of joining the EU, it has become evident that modernization and maintenance of its fleet are required as the country is likely to receive more foreign investment and engage in international cooperation projects. Furthermore, the Danube Strategy has been adopted with the aim of synchronizing the activities of the Danube region countries for sustainable development.

Improvement and stimulation of water transport development are crucial for economic prosperity of the region as water transport is a good alternative to road and rail transport, it is also energy efficient and environmentally safe. According to the General Transport Master Plan of the Republic of Serbia (2009), the aim is to increase of the share of water transport in cargo and freight transportation and to modernize the river fleet. Hence, it is extremely important to implement the system of the River Information Services that would cut transportation time and make transportation more cost effective.

Intermodal transport development is recognised as yet another factor contributing to sustainable economic development of Serbia. The Danube in particular has several high priority projects which could finally improve the condition of the navigation: for example, removal of the sunken German ships and unexploded bombs left from World War II near Prahovo. Another key project is the reconstruction of the ship locks Djerdap I and Djerdap II and construction of a new bridge near Novi Sad.

Surprisingly, in our research we faced difficulties when gathering data on the use of the Danube inland waterways: the statistical data provided by official sources are often inaccurate, moreover, such data are often hard to obtain. For instance, cruise tourists are excluded from the data on the overall tourist turnover by the Statistical Office, although they on average spend 2-3 days in national waters.

This study has provided evidence that more attention should be devoted to trans-border cooperation in the Danube region. Further research is necessary into the problem of inadequate communication between border regions, particularly if such regions share renewable energy resources.

\section{References}

1. Štetić, S. (2007). Special Forms of Tourism. Belgrade.

2. Milanković, J. (2015). Danube as a Transport Artery and Axis of Development in the Republic of Serbia (PhD thesis). Novi Sad: Faculty of Sciences, Department of Geography, Tourism and Hotel Management.

3. Dragin, A., Jovičić, D. \& Bošković, D. (2010). Economic Impact of Cruise Tourism Along the Pan-European Corridor VII. Economic Research. 23(4), 127-141. doi: $\underline{10.1080 / 1331677 X .2010 .11517438}$

4. Radmilović, Z., \& Maraš, V. (2011). Role of Danube Inland Navigation in Europe. International Journal for Traffic and Transport Engineering, 1(1), 28-40. Retrieved from http://ijtte.com/ uploads/2011-04-16/d4c8811d-9674-f24aIJTTE\%20r01\%2028-40.pdf

5. Rissoan J. P. (1994). River-Sea Navigation in Europe. Journal of Transport Geography, 2(2), $131-142$.

6. Wiegmans, B. W., Masurel, E. \& Nijkamp, P. (1999). Intermodal Freight Terminals: An Analysis of the Terminal Market. Transportation Planning \& Technology, 23(2), 105-128. doi: $\underline{10.1080 / 03081069908717643}$

7. Mihić, S., Golušin, M. \& Mihajlović, M. (2011). Policy and Promotion of Sustainable Inland Waterway Transport in Europe-Danube River. Renewable and Sustainable Energy Reviews, 15(4), 1801-1809. doi: 10.1016/j.rser.2010.11.033

8. Dragin, A. (2010). International Cruising the Corridor 7. Novi Sad: University of Novi Sad, Department of Geography, Tourism and Hotel Management.

9. Dragin, A., Dragin, V., Košić, K., Demirović, D., Ivkov-Džigurski, A. (2017). Tourists Motives and Residents Attitude towards Cruisers. In: Southern and Eastern Europe 2017: Tourism and 
Creative Industries: Trends and Challenges: $4^{\text {th }}$ International Scientific Conference, Opatija, Croatia, 4-6 May 2017. Vol. 4 (pp. 133-144). Opatija: University of Rijeka, Faculty of Tourism and Hospitality Management. doi: $10.20867 /$ tosee.04.42

10. Demonja, D. (2012). The Importance of the Danube Strategy for Tourism and Culture Development of the Croatian Danube Region. Geographica Pannonica, 16(3), 112-125. doi: 10.5937/ GeoPan1203112D

11. Vujko, A., \& Gajić, T. (2014). Opportunities for Tourism Development and Cooperation in the Region by Improving the Quality of Tourism Services-the 'Danube Cycle Route' Case Study. Economic Research-Ekonomska istraživanja, 27(1), 847-860. doi: 10.1080/1331677X.2014.975517

12. Dragićević, S., Mészáros, M., Djuridjić, S., Pavić, D., Novković, I., \& Radislav, T. (2013). Vulnerability of National Parks to Natural Hazards in the Serbian Danube Region. Polish Journal of Environmental Studies, 22(4), 1053-1060. Retrieved from https://www.researchgate.net/publication/255828318 Vulnerability of National Parks to Natural Hazards in the Serbian Danube Region

13. Lukić, D., Berjan, S., \& El Bilali, H. (2018). Indicators of Tourism Development of the Serbian Danube Region. R-Economy, 4(1), 30-37. Retrieved from http://r-economy.ru/wp-content/uploads/2018/03/r-economy 2018_v4 1 05.pdf

\section{Information about the authors}

Jelena Milanković Jovanov - PhD in Geosciences, Teaching Assistant at the Department of Geography, Tourism and Hotel Management, Faculty of Sciences, University of Novi Sad (1 Dr Zorana Đinđića, 21101 Novi Sad, Republic of Serbia); e-mail: milankovicjovanov@gmail.com.

Dragoslav Pavić - PhD in Geosciences, Full Professor at the Department of Geography, Tourism and Hotel Management, Faculty of Sciences, University of Novi Sad (1 Dr Zorana Đinđića, 21101 Novi Sad, Republic of Serbia); e-mail: dragoslav.pavic@dgt.uns.ac.rs.

Jasmina Đorđević - PhD in Geosciences, Full Professor at the Department of Geography, Tourism and Hotel Management, Faculty of Sciences, University of Novi Sad (1 Dr Zorana Đinđića, 21101 Novi Sad, Republic of Serbia); e-mail: jasminadjordjevic@live.com.

Aleksandra Dragin - PhD in Geosciences, Associate Professor at the Department of Geography, Tourism and Hotel Management, Faculty of Sciences, University of Novi Sad (1 Dr Zorana Đinđića, 21101 Novi Sad, Republic of Serbia); e-mail: aleksandra.dragin@dgt.uns.ac.rs.

Smiljana Đukičin Vučković - PhD in Geosciences, Assistant Professor at the Department of Geography, Tourism and Hotel Management, Faculty of Sciences, University of Novi Sad (1 Dr Zorana Đinđića, 21101 Novi Sad, Republic of Serbia); e-mail: smiljanadjukicin@gmail.com.

Minucsér Mészáros - PhD in Geosciences, Assistant Professor at the Department of Geography, Tourism and Hotel Management, Faculty of Sciences, University of Novi Sad (1 Dr Zorana Đinđića, 21101 Novi Sad, Republic of Serbia); e-mail: minucer.mesaros@dgt.uns.ac.rs. 